Hamm, M. and Greer, C. (2011) 'Into the Future, Darkly', in Crime Media Culture: An International Journal, 7, 1: 3-4.

\title{
Into the Future, Darkly
}

As Volume 7, Issue 1 of Crime, Media, Culture leaves for our presses in New Delhi, winds carrying radioactive iodine from Japan's decimated Fukushima Daiichi nuclear plant are headed for Tokyo. With hundreds already dead and tens of thousands homeless in Japan's greatest environmental catastrophe, government officials stand accused of massive incompetence and systemic institutional failure in dealing with the crisis. While experiments in indigenous populism have recently cracked opened new democratic vistas in Egypt and Tunisia, in Libya government snipers are shooting protestors from artillery helicopter gunships as thugs armed with hammers and swords attack families in their homes - all of this in an attempt to weaken opposition from students, intellectuals and the middle class through the wholesale destruction of urban culture. Confronted with challenges never before encountered, and social institutions no longer a viable frame of reference for human action, people the world over are seeking alternative ways to organize their lives. Faced with ecological disaster, government corruption, police repression, torture and economic dead ends, millions leave their homes each year for promised lands abroad. Others remain and organize themselves into resistance movements. Today, these activists increasingly are turning to social media to bring attention to their growing discontent. Facebook is used to schedule protests, Twitter to coordinate events, and the world is simultaneously informed, enthralled and scandalized through You Tube and Wikileaks. 
It comes as no surprise, then, that scholars of crime and justice are also being pulled by the dark prospects of liquid modernity. CMC Volume 7, Issue 1 is a testament to those risks. We begin with a topic familiar to readers of this journal. In 'Images of Torture,' Eamonn Carrabine moves beyond traditional explanations of the Abu Ghraib torture scandal - typically lodged in American visions of popular culture - by arguing that the visual power of the Abu Ghraib photographs are consistent with a European classical art tradition. Through this unique framing, Carrabine irradiates the complex ways that moral relations between strangers are mediated in the modern world. The relationship between media consumption and punitive criminal justice policies has long interested criminologists. Yet this work has been limited primarily to media consumers in the United States and Britain. Ray Surette and colleagues provide a corrective to this shortcoming in 'Preventative and Punitive Criminal Justice Policy Support in Trinidad.' Through a national telephone survey of residents in Trinidad and Tobago, the researchers find that crime dramas are perceived as reality while crime news is typically perceived as accurate yet neither finding is an especially strong predictor of support for the punishment of criminal transgressors.

An estimated 200 million people are migrants around the world today. About 9 million of them are Mexican citizens who have entered the United States as undocumented workers. This highly contentious policy issue is addressed by Hille Koskela in 'Don't Mess with Texas!' Koskela examines the government-funded Texas Virtual Watch Program through the lens of contemporary surveillance theory, elucidating the frames by which authorities justify the (failed) multi-million dollar border control effort. In so doing, Koskela provides fascinating accounts of voluntary citizen participation in the program, couched in an emerging 'culture of 
informing', aided and abetted by the USA Patriot Act of the post-9/11 era. Scholars of the migration issue typically focus on social and economic impacts. In 'Neo-Nazis and Moral Panic,' Revital Sela-Shayovitz rivets her attention on moral vicissitudes by examining the emergence of a neo-Nazi gang in Israel. The gang is comprised of young Jewish men who emigrated from Russia, and they are examined through Israeli news coverage and a major policy development in the Knesset. The tragic irony of uncovering neo-Nazis in 'a society living in the shadows of the Holocaust' is made palpable by Sela-Shayovitz, who concludes that the episode increased social control by the reconfiguration of dangers facing the Jewish state. The Articles section in this first issue of Volume 7 ends with a study of horror. In 'A "System of light before being a figure of stone,"' Michael Fiddler offers a sophisticated historical treatise on Victorian prison architecture. For Fiddler, prison architecture offers a portal through which we may understand the 'ghostly, shimmering unity of meaning' behind carceral control. Finally, Giles Price's photographic essay explores the changing nature of the visual documentation of public protest as evidenced at the G20 Summit in London on $1^{\text {st }}$ April 2009. It also provides clear evidence of the unique place of the professional photographer within this crowded and increasingly amateur visual milieu. Price's photography documents the chaotic visual environment at G20, from the police use of helicopters and specialist teams of officers video recording the crowd, to the media in all their guises, to the protesters and citizen journalists. The ubiquity of the camera constitutes a high surveillance context within which actions of all parties can be recorded and scrutinised.

We would also like to announce a significant development within CMC. By the time this short Editorial and $C M C 7,1$ are published, we will have launched the new SAGETrack platform. 
This online system, already in use across many leading journals, has been designed with the aim of maximizing the speed, efficiency and transparency of the submission and peer review process. It should make life easier for authors, editors and reviewers alike. All future submissions should be made online through the SAGETrack system, which can be accessed via the main $\mathrm{CMC}$ website here: http://cmc.sagepub.com/. As ever, we look forward to receiving your submissions and working with you soon. 